Note

\section{The Environmental Factors Affecting Sporulation of an Alkalophilic Bacillus Species}

\section{Toshiaki Kudo and Koki HorıKosHI}

\author{
The Institute of Physical and Chemical Research, \\ Wako-shi, Saitama-ken 351
}

Received July 4, 1979

There are many reports about the study of alkalophilic bacteria. ${ }^{1-4)}$ These alkalophilic bacteria grew well under alkaline conditions, and $\mathrm{NaCl}\left(\mathrm{Na}^{+}\right)$was necessary for their growth. $\mathrm{Na}^{+}$ion also stimulated the transport of amino acids into the cells. ${ }^{3)}$ It was found that the optimum $\mathrm{pH}$ for germination of spores of alkalophilic Bacillus species was about 10 and $\mathrm{Na}^{+}$ ion stimulated the initiation of germination specifically (in perparation). But, there has been no report about the study of sporulation of alkalophilic Bacillus species. In this note, we will present the medium for sporulation of alkalophilic Bacillus species and the effect of environmental factors $(\mathrm{pH}$, temperature and $\mathrm{NaCl}$ concentration) affecting sporulation.

An alkalophilic Bacillus no. 2b-2 isolated from soil was used throughout out the experiments because of its excellencein yield of spores. Alkalophilic Bacillus no. 16-2 and Bacillus no. 20 were used for comparative purposes. Taxonomic studies of these strains will be reported elsewhere.

As for as tested (exanimed), alkaline modified Schaeffer medium (AMS medium) was found to be the best medium for sporulation of alkalophilic Bacillus species, Bacillus no. 2b-2, Bacillus no. 16-2 and Bacillus no. 20. Therefore, we used the ASM medium for the experiments described below.

Table I shows the effect of $\mathrm{pH}$ on sporulation of Bacillus species. There seemed to be a general agreement that the optimum $\mathrm{pH}$ for sporulation was close to that for growth, but the range was narrow. The final $\mathrm{pH}$ in the medium became $9 \sim 9.5$ irrespective of initial pH. It was also found that the sporulation rate was related to the funal optical density. The optimum temperature for sporulation was almost the same as that for growth (Table II). The growth at $45^{\circ} \mathrm{C}$ was faster than that at $34^{\circ} \mathrm{C}$, but the sporulation rate at $45^{\circ} \mathrm{C}$ was much lower than that at $34^{\circ} \mathrm{C}$. Filamentous cells $(5 \sim 6$ times longer than the normal size) were observed at $45^{\circ} \mathrm{C}$, and cell division found to be slightly inhibited. Considering that sporulation is a kind of cell division in a special condition, 5 ) the lower sporulation rate at $45^{\circ} \mathrm{C}$ may be related
Table II. Effect of Various Temperature on Sporulation of Bacillus No. 2b-2

\begin{tabular}{cccc}
$\begin{array}{c}\text { Tempera- } \\
\text { ture } \\
\left({ }^{\circ} \mathrm{C}\right)\end{array}$ & $\begin{array}{c}\text { Final } \\
\text { OD }{ }^{a}{ }^{\circ}\end{array}$ & $\begin{array}{c}\text { Growth } \\
\text { Rate }\end{array}$ & $\begin{array}{c}\text { Percent of } \\
\text { sporulation }\end{array}$ \\
\hline 25 & 4.4 & 130 & $5 \%$ \\
34 & 4.4 & 45 & 95 \\
37 & 4.4 & 40 & 95 \\
45 & 3.0 & 43 & 1 \\
55 & 0.0 & - & - \\
\hline
\end{tabular}

AMS medium ( $\mathrm{pH}$ 9.6) was used, and the details of the experiment are noted in Table I.

$a$ The final OD and the sporulation rate were measured after $42 \mathrm{hr}$ of incubation.

Table III. EfFect of NaCl Concentration on Sporulation of Bacillus No. 2b-2

\begin{tabular}{cccc}
$\begin{array}{c}\mathrm{NaCl} \\
\begin{array}{c}\mathrm{Nancentra-} \\
\text { tion }\end{array}\end{array}$ & $\begin{array}{c}\text { Final } \\
\mathrm{OD}^{a}\end{array}$ & $\begin{array}{c}\text { Growth } \\
\text { Rate }\end{array}$ & $\begin{array}{c}\text { Percent of } \\
\text { sporulation }\end{array}$ \\
\hline $0 \mathrm{M}$ & 2.9 & 54 & $0 \%$ \\
0.02 & 3.7 & 46 & $30-40$ \\
0.2 & 4.7 & 44 & 70 \\
0.4 & 4.0 & 44 & $30-40$ \\
1 & 2.9 & 46 & 1 \\
\hline
\end{tabular}

AMS medium ( $\mathrm{pH} \mathrm{9.6)} \mathrm{was} \mathrm{used,} \mathrm{and} \mathrm{the} \mathrm{details} \mathrm{of}$ the experiments are noted in Table I.

a The final $\mathrm{OD}$ and the sporulation rate were measured after $47 \mathrm{hr}$ of incubation at $37^{\circ} \mathrm{C}$.

to the inhibition of cell division at $45^{\circ} \mathrm{C}$. Table III shows the effect of $\mathrm{NaCl}$ concentration on the sporulation of Bacillus no. 2b-2. The optimun concentration of $\mathrm{NaCl}$ for sporulation was similar to that for growth, but the range was narrow.

In conclusion, it was found that the optimum conditions for sporulation were almost the same as those for growth, and alkalophilic Bacillus no. 2b-2 had the characteristics that it sporulated very well in the AMS medium (initial $\mathrm{pH} 8 \sim 9.5$ ) at $37^{\circ} \mathrm{C}$, and $0.2 \mathrm{M}$ $\mathrm{NaCl}$ was necessary for the optimum sporulation.

\section{REFERENCES}

1) K. Horikoshi, Agric. Biol. Chem., 35, 1783 (1971).

2) Y. Ikura and K. Horikoshi, ibid., 42, 753 (1978).

3) M. Kitada and K. Horikoshi, J. Bacteriol., 131, 784 (1977).

4) T. Kudo and K. Horikoshi," Spores VII," ed. by G. Chambliss and J. C. Vary, American Society for Microbiology, Washington, D. C., 1978, p. 220.

5) A. D. Hitchis and R. A. Slepecky, Nature, 223, 804 (1969). 


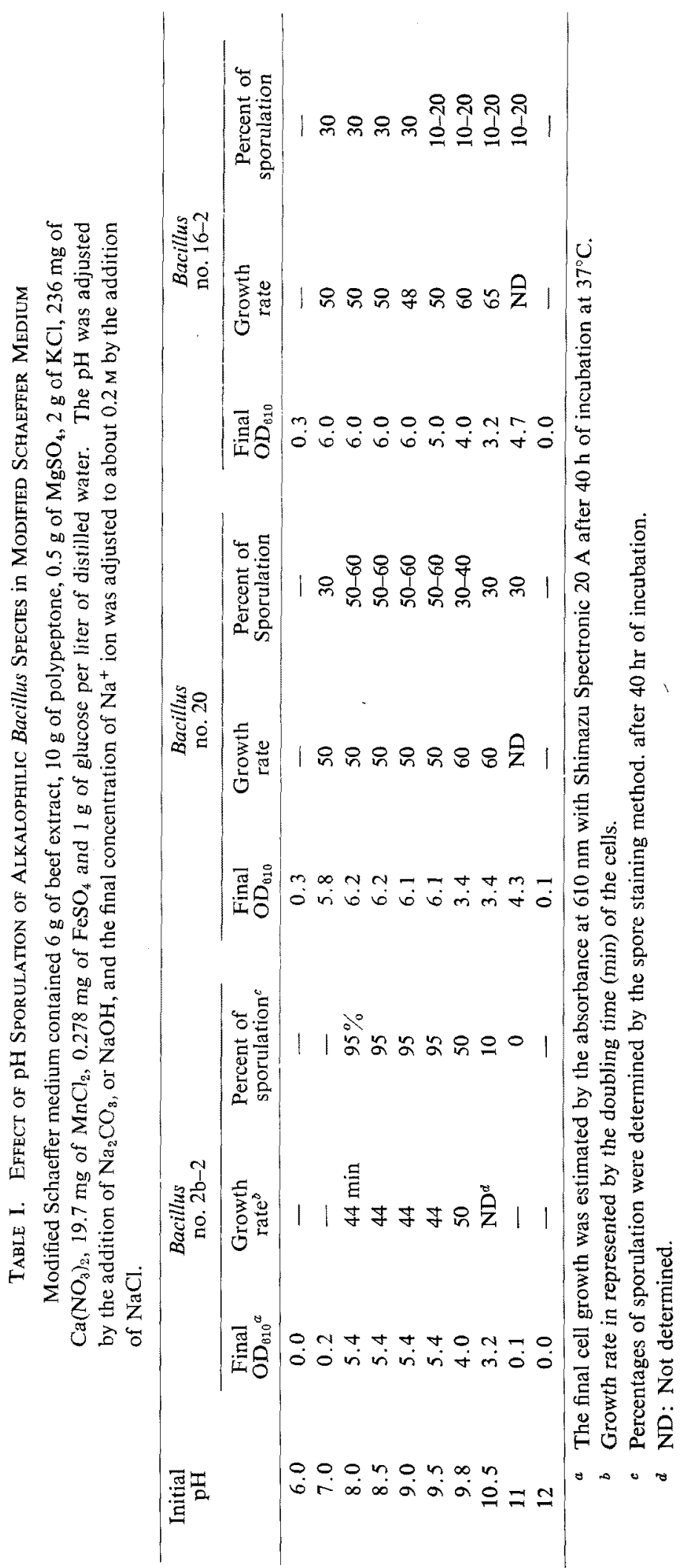

